\title{
Milk production responses to altering the dietary ratio of palmitic and oleic acids varies with production level in dairy cows
}

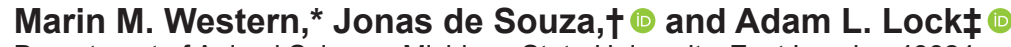 \\ Department of Animal Science, Michigan State University, East Lansing 48824
}

\begin{abstract}
We evaluated the effects of altering the dietary ratio of palmitic (C16:0; PA) and oleic (cis-9 C18:1; $\mathrm{OA}$ ) acids on production responses of cows with a wide range of milk production (32 to $65 \mathrm{~kg} / \mathrm{d}$ ) in a crossover design experiment with a preliminary period. Thirty-two multiparous Holstein cows $(144 \pm 54 \mathrm{~d}$ in milk) were assigned randomly to a treatment sequence. Treatments were diets supplemented with fatty acid (FA) blends (1.5\% of diet dry matter) that provided 80\% C16:0 + 10\% cis-9 C18:1 (PA) and 60\% C16:0 + $30 \%$ cis-9 C18:1 (PA+OA). The corn silage and alfalfabased diets contained $20.0 \%$ forage neutral detergent fiber (NDF), $28.5 \%$ starch, and $17.1 \%$ crude protein. Treatment periods were $21 \mathrm{~d}$ with the final $5 \mathrm{~d}$ used for data and sample collection. Treatment did not affect dry matter intake (DMI), milk yield, energy-corrected milk (ECM), body weight, or body weight change. The $\mathrm{PA}+\mathrm{OA}$ diet increased total, 16-carbon, and 18-carbon FA digestibility compared with the PA diet. Compared with $\mathrm{PA}+\mathrm{OA}, \mathrm{PA}$ increased fat yield (1.97 vs. 1.91 $\mathrm{kg} / \mathrm{d}$ ) and protein yield (1.61 vs. $1.55 \mathrm{~kg} / \mathrm{d})$. The PA diet also increased the yield of de novo (448 vs. $428 \mathrm{~g} / \mathrm{d}$ ) and mixed (749 vs. $669 \mathrm{~g} / \mathrm{d}$ ) milk FA and decreased the yield of preformed FA (605 vs. $627 \mathrm{~g} / \mathrm{d}$ ) compared with $\mathrm{PA}+\mathrm{OA}$. Interactions were detected between treatment and preliminary milk yield for DMI, total FA intake, 16-carbon FA intake, ECM, 3.5\% fat-corrected milk (linear interaction), and a tendency for milk yield (linear interaction); lower-producing cows $(<45 \mathrm{~kg} / \mathrm{d}$ ) had increased DMI and ECM on the PA diet, whereas higher-producing cows $(>55 \mathrm{~kg} / \mathrm{d})$ had increased DMI and $\mathrm{ECM}$ on the $\mathrm{PA}+\mathrm{OA}$ diet. A linear interaction was detected between treatment and preliminary milk yield for mixed milk FA yield (linear interaction) and a tendency for de novo milk FA yield (linear interaction). Our results demonstrate that feeding a fat supplement
\end{abstract}

Received May 21, 2020.

Accepted August 5, 2020.

*Current address: Vita Plus Corporation, Madison, WI 53725

†Current address: Perdue Agribusiness, Salisbury, MD 21804.

‡Corresponding author: allock@msu.edu containing more cis-9 C18:1 replacing C16:0 increased production responses (DMI, milk yield, and ECM) in higher-producing cows, but decreased production responses in lower-producing cows.

Key words: palmitic acid, milk production, production response, cis-9 C18:1, C16:0

\section{INTRODUCTION}

Supplemental fat is often added to dairy cow rations to increase energy density and improve milk production and milk fat yield (Palmquist and Jenkins, 2017). Recent research has focused on the effects of supplemental fat on milk production, nutrient digestibility, and metabolism (Rico et al., 2014a; de Souza et al., 2018; Western et al., 2020). Although, in general, fat supplementation has been shown to increase milk yield, the efficiency of milk production, and reproductive performance, great variation has been reported for different fat types and, indeed, the same supplement across different diets and studies (Rabiee et al., 2012; Rodney et al., 2015). Palmitic (C16:0), stearic (C18:0), and oleic (cis-9 C18:1) acids are the 3 main fatty acids (FA) present in milk fat and adipose tissue of dairy cows (Palmquist, 2006; Douglas et al., 2007). Understanding the differences between individual FA is crucial to determining optimal dietary FA profiles for cows. Recent research indicates that C16:0 supplementation increases milk fat concentration and yield and NDF digestibility compared with non-FA-supplemented control diets and other FA supplements (de Souza and Lock, 2018b; Western et al., 2020). Boerman et al. (2017) fed increasing levels of a C18:0-enriched supplement ( $~ 93 \%$ C18:0) to dairy cows and observed no positive effect on production responses, which was likely associated with the pronounced decrease in total FA digestibility as FA intake increased. In post-peak cows, we recently observed that feeding a FA blend with a high content of C16:0 (80\% C16:0) increased milk energy output and energy partitioning toward milk, whereas feeding a FA blend with a combination of C16:0 and cis-9 C18:1 (45\% C16:0 and 35\% cis-9 C18:1) increased energy allocated to BW and the partitioning of energy to BW compared with a non-fat-supplemented diet (de Souza 
et al., 2018). Interestingly, feeding cis-9 C18:1 not only increased BW gain in post-peak cows but also plasma insulin compared with non-FA-supplemented control diets and other FA supplements (de Souza et al., 2018, 2019). Altogether, these results suggest that C16:0 and cis-9 C18:1 are able to alter nutrient partitioning between the mammary gland and adipose tissue, which may allow for different FA supplements to be used in different situations according to the metabolic priority of dairy cows and management needs. Therefore, determining the response of dairy cows to different FA blends containing $\mathrm{C} 16: 0$ and cis-9 $\mathrm{C} 18: 1$ is of particular importance.

It is established that production responses to dietary changes are affected by the production level of cows (e.g., Harvatine and Allen, 2005; Piantoni et al., 2015). Supplementation with C16:0 has been shown to increase milk fat yield regardless of the level of milk production (Piantoni et al., 2013; Rico et al., 2014b). Recently, we evaluated different ratios of C16:0 and cis-9 C18:1 in dairy cows with different production levels (de Souza et al., 2019) and observed that higherproducing cows showed linear increases in ECM as the level of cis-9 C18:1 increased in the FA blend (from 10 to $30 \%$ of cis-9 C18:1), whereas lower-producing cows showed linear decreases in ECM as the amount of cis-9 C18:1 increased in the FA blend. de Souza et al. (2019) also reported an interaction between FA treatment and production level for plasma insulin because increasing dietary cis-9 C18:1 in FA treatments linearly increased plasma insulin in low-producing cows while quadratically affecting insulin in high-producing cows. Therefore, these changes in nutrient partitioning driven by feeding different FA blends could be related to specific hormonal changes and are likely related to the production level of the cows. Although this study included 3 production groups, the range in milk production was only $15 \mathrm{~kg} / \mathrm{d}$, with milk yield in the low group averaging $45 \mathrm{~kg} / \mathrm{d}$ and that in the high group $60 \mathrm{~kg} / \mathrm{d}$. Therefore, the objective of our study was to evaluate the effects of different ratios of $\mathrm{C} 16: 0$ and cis-9 C18:1 on production responses, nutrient digestibility, and milk FA profile of lactating cows across a wide range of milk production $(31-66 \mathrm{~kg} / \mathrm{d})$. Our hypothesis was that increasing cis-9 C18:1 would increase production parameters in higher-producing cows while not having an effect in lower-producing cows.

\section{MATERIALS AND METHODS}

\section{Design and Treatments}

Experimental procedures were approved by the Institutional Animal Care and Use Committee at Michigan
State University. This study was designed to test feeding FA blends with varying ratios of $\mathrm{C} 16: 0$ and cis-9 C18:1 to cows across a wide range of milk production. Crossover studies with a wide range of production have been used previously to assess interactions between production level and different nutrition strategies (Harvatine and Allen, 2005; Piantoni et al., 2015).

Thirty-two mid-lactation (mean \pm SD: $144 \pm 54$ DIM, $714 \pm 51 \mathrm{~kg}$ of BW, and $48.0 \pm 9.5 \mathrm{~kg} / \mathrm{d}$ of milk) Holstein cows with a wide range in milk yield (31.1 to $65.7 \mathrm{~kg} / \mathrm{d}$ ) from the Michigan State University Dairy Field Laboratory were randomly assigned to treatment sequence in a crossover design experiment with 21-d periods preceded by a 14-d preliminary period. The 2 treatments were combinations of 2 commercially available FA supplements (Nutracor and Nutracal; Wawasan Agrolipids, Johor, Malaysia) that differed in FA profile and were blended to achieve different ratios of $\mathrm{C} 16: 0$ and cis-9 C18:1 in the FA supplement blends (Table 1). The FA treatments were (1) 80\% C16:0, 10\% cis-9 C18:1 (PA), and (2) 60\% C16:0, 30\% cis-9 C18:1 (PA+OA). The supplement blends were fed at $1.5 \% \mathrm{FA}(\%$ of diet DM). Cows $(\mathrm{n}=16)$ in treatment sequence $\mathrm{A}$ (received treatment 1 in period 1 and treatment 2 in period 2) averaged $47.8 \pm 9.8 \mathrm{~kg}$ with a range in milk yield between 31.1 and $65.7 \mathrm{~kg} / \mathrm{d}$. Cows $(\mathrm{n}=$ 16 ) in treatment sequence $B$ (received treatment 2 in period 1 and treatment 1 in period 2) averaged $48.2 \pm$

Table 1. Proportion of fatty acid (FA) supplements used to make FA blends and FA profile of blends fed during the treatment periods ${ }^{1}$

\begin{tabular}{lcc}
\hline & \multicolumn{2}{c}{ Treatment $^{2}$} \\
\cline { 2 - 3 } Variable & PA & PA+OA \\
\hline \% of each FA supplement in the treatment & & \\
blend & & \\
C16:0-enriched FA supplement & \\
Calcium salt of palm FA supplement & & \\
FA profile of each treatment blend, & 91.0 & 41.0 \\
g/100 g of FA & & 59.0 \\
C14:0 & & \\
C16:0 & 0.74 & 0.82 \\
C18:0 & 81.4 & 59.7 \\
cis-9 C18:1 & 1.51 & 2.93 \\
cis-9, cis-12 C18:2 & 11.3 & 29.5 \\
cis-9, cis-12,cis-15 C18:3 & 2.44 & 5.89 \\
\hline
\end{tabular}

${ }^{1}$ Average $(\mathrm{n}=2)$ composition of FA supplements based on samples taken during collection periods.

${ }^{2} \mathrm{PA}=1.5 \%$ of $\mathrm{FA}$ blend providing $80 \% \mathrm{C} 16: 0$ and $10 \%$ cis-9 $\mathrm{C} 18: 1$; $\mathrm{PA}+\mathrm{OA}=1.5 \%$ of $\mathrm{FA}$ blend providing $60 \% \mathrm{C} 16: 0$ and $30 \%$ cis-9 C18:1.

${ }^{3}$ Palmitic acid-enriched FA supplement (Nutracor; Wawasan Agrolipids, Johor, Malaysia). The supplement contained (g/100 g of FA) 0.73 of $\mathrm{C} 14: 0,85.2$ of $\mathrm{C} 16: 0,1.32$ of $\mathrm{C} 18: 0,10.2$ of $\mathrm{C} 18: 1$ cis-9, and $98 \%$ total FA.

${ }^{4}$ Ca salts of palm FA supplement (Nutracal; Wawasan Agrolipids). The supplement contained (g/100 g of FA) 0.88 of C14:0, 41.9 of $\mathrm{C} 16: 0$, 4.04 of $\mathrm{C} 18: 0,42.9$ of C18:1 cis-9, and $82 \%$ total FA. 
$9.1 \mathrm{~kg}$ with a range in milk yield between 31.6 and 62.7 $\mathrm{kg} / \mathrm{d}$.

The ingredient and nutrient compositions of the diets fed as a TMR are presented in Table 2. Diets were formulated to meet requirements of the average cow in the group according to NRC (2001). Dry matter concentration of forages was determined twice weekly and diets were adjusted when necessary. Throughout the experiment, cows were housed in individual tie stalls. Cows were milked twice a day (0300 and $1400 \mathrm{~h})$. Access to feed was blocked daily from 0800 to $1000 \mathrm{~h}$ to allow for the collection of orts and offering of feed. Cows were fed $115 \%$ of expected daily intake, and feed intake was recorded daily. Water was available ad libitum and

Table 2. Ingredient and nutrient composition of treatment diets

\begin{tabular}{|c|c|c|}
\hline \multirow[b]{2}{*}{ Composition } & \multicolumn{2}{|c|}{ Treatment $^{1}$} \\
\hline & PA & $\mathrm{PA}+\mathrm{OA}$ \\
\hline \multicolumn{3}{|l|}{ Ingredient, $\%$ of DM } \\
\hline Ground corn & 27.9 & 27.9 \\
\hline Corn silage & 24.0 & 24.0 \\
\hline Haylage & 18.9 & 18.9 \\
\hline Soybean meal & 12.8 & 12.8 \\
\hline Soyhulls & 4.28 & 4.16 \\
\hline Cottonseed & 3.43 & 3.43 \\
\hline Vitamin mineral $\operatorname{mix}^{2}$ & 3.25 & 3.25 \\
\hline Wheat straw & 2.57 & 2.57 \\
\hline Amino acid supplement ${ }^{3}$ & 1.29 & 1.29 \\
\hline C16:0-enriched fatty acid supplement ${ }^{4}$ & 1.44 & 0.63 \\
\hline Calcium salt palm fatty acid supplement ${ }^{5}$ & 0.14 & 1.08 \\
\hline \multicolumn{3}{|l|}{ Nutrient, \% of DM } \\
\hline NDF & 27.9 & 27.8 \\
\hline Forage NDF & 20.0 & 20.0 \\
\hline $\mathrm{CP}$ & 17.0 & 17.0 \\
\hline Starch & 28.5 & 28.5 \\
\hline Fatty acids & 4.41 & 4.42 \\
\hline $16: 0$ & 2.00 & 1.61 \\
\hline 18:0 & 0.11 & 0.13 \\
\hline cis-9 18:1 & 0.69 & 0.99 \\
\hline cis-9,cis-12 18:2 & 1.31 & 1.35 \\
\hline cis-9,cis-12,cis-15 18:3 & 0.20 & 0.20 \\
\hline
\end{tabular}

${ }^{1} \mathrm{PA}=1.5 \%$ of fatty acid (FA) blend providing $80 \% \mathrm{C} 16: 0$ and $10 \%$ cis-9 $\mathrm{C} 18: 1 ; \mathrm{PA}+\mathrm{OA}=1.5 \%$ of $\mathrm{FA}$ blend providing $60 \% \mathrm{C} 16: 0$ and 30\% cis-9 C18:1.

${ }^{2}$ Vitamin and mineral mix contained $34.1 \%$ dry ground shelled corn, $25.6 \%$ white salt, $21.8 \%$ calcium carbonate, $9.1 \%$ Biofos (The Mosaic Co., Plymouth, MN), $3.9 \%$ magnesium oxide, $2 \%$ soybean oil, and $<1 \%$ of each of the following: manganese sulfate, zinc sulfate, ferrous sulfate, copper sulfate, iodine, cobalt carbonate, vitamin E, vitamin A, vitamin $\mathrm{D}$, and selenium.

${ }^{3}$ Spectrum Agriblue (Perdue Agribusiness, Salisbury, MD).

${ }^{4}$ Palmitic acid-enriched FA supplement (Nutracor; Wawasan Agrolipids, Johor, Malaysia). The supplement contained (g/100 g of fatty acid) 0.73 of C14:0, 85.2 of C16:0, 1.32 of C18:0, 10.2 of C18:1 cis-9, and $98 \%$ total fatty acids.

${ }^{5} \mathrm{Ca}$ salts of palm FA supplement (Nutracal; Wawasan Agrolipids). The supplement contained $(\mathrm{g} / 100 \mathrm{~g}$ of fatty acid) 0.88 of C14:0, 41.9 of $\mathrm{C} 16: 0,4.04$ of $\mathrm{C} 18: 0,42.9$ of $\mathrm{C} 18: 1$ cis-9, and $82 \%$ total fatty acids. each stall was bedded with sawdust and cleaned twice per day.

\section{Data and Sample Collection}

Preliminary milk yield (PMY) was determined during the last $3 \mathrm{~d}$ of the preliminary period. Samples and data for production and digestibility variables, as well as plasma metabolites, were collected during the last 5 $\mathrm{d}$ of each treatment period (d 17 to 21$)$. Samples $(0.5$ $\mathrm{kg}$ ) of all diet ingredients and orts (12.5\%) from each cow were collected daily during the sampling period and composited by period for analysis. Fecal ( $\sim 400 \mathrm{~g})$ and blood $(\sim 15 \mathrm{~mL})$ samples were collected every $15 \mathrm{~h}$ during the last $5 \mathrm{~d}$ of each treatment period, totaling 8 samples per cow per period. The 15 -h interval over $5 \mathrm{~d}$ simulates sampling every $3 \mathrm{~h}$ across a 24 -h period. Feces were stored in a sealed plastic container at $-20^{\circ} \mathrm{C}$. Blood was stored on ice until centrifugation at 3,000 $\times g$ for $15 \mathrm{~min}$ at $4^{\circ} \mathrm{C}$ (within $30 \mathrm{~min}$ of sample collection). Plasma was transferred into microcentrifuge tubes and stored at $-20^{\circ} \mathrm{C}$ until composited by period. Milk yield was recorded and 2 milk samples collected at each milking. One aliquot was collected and sealed in a tube with preservative (Bronopol tablet; D\&F Control Systems, San Ramon, CA) and stored at $4^{\circ} \mathrm{C}$ for milk component analysis. The second aliquot was stored without preservative at $-20^{\circ} \mathrm{C}$ until analyzed for $\mathrm{FA}$ composition.

Body weight measurements were taken 3 times per week throughout the study following the afternoon milking, and BW change was calculated according to Boerman et al. (2015b). On the last day of the preliminary period and the last day of each treatment period, 3 trained investigators determined BCS on a 5-point scale in 0.25-point increments (Wildman et al., 1982).

\section{Sample Analysis}

Diet ingredients, orts, and fecal samples were dried at $55^{\circ} \mathrm{C}$ in a forced-air oven for $72 \mathrm{~h}$ for DM determination. Dried samples were ground with a Wiley mill (1 mm-screen; Arthur H. Thomas, Philadelphia, PA). Feed ingredients, orts, and feces were analyzed for NDF, CP, starch, and FA concentration as described by Boerman et al. (2017). Indigestible NDF was determined after $240 \mathrm{~h}$ of in vitro fermentation (Goering and Van Soest, 1970). Fatty acid concentrations of feed ingredients were determined as described by Lock et al. (2013).

Plasma nonesterified fatty acids (NEFA) and BHB were analyzed using an Olympus AU640e chemistry analyzer (Olympus America, Center Valley, PA) at the Diagnostic Center for Population and Animal Health at 
Michigan State University (East Lansing, MI). Plasma insulin concentrations were determined by ELISA (Bovine Insulin ELISA; Mercodia AB, Uppsala, Sweden).

Milk samples were analyzed for fat, true protein, and lactose concentrations by mid-infrared spectroscopy (AOAC, 1990; method 972.160; Universal Lab Services, Lansing, MI). Yields of 3.5\% FCM, ECM, milk energy, and milk components were calculated using milk yield and component concentrations from each milking, summed for a daily total, and averaged for each collection period. Fat-corrected milk was calculated as: $3.5 \%$ $\mathrm{FCM}=[(0.4324 \times \mathrm{kg}$ of milk $)+(16.216 \times \mathrm{kg}$ of milk fat)]. Energy-corrected milk was calculated as: ECM $=[(0.327 \times \mathrm{kg}$ of milk $)+(12.95 \times \mathrm{kg}$ of milk fat $)+$ $(7.20 \times \mathrm{kg}$ of milk protein)]. Milk samples used for analysis of FA composition were composited based on milk fat yield (d 17 to 21 of each period). Milk lipids were extracted and FAME prepared and quantified using gas-liquid chromatography, according to Lock et al. (2013). Yields of individual FA (g/d) in milk fat were calculated by using milk fat yield and FA concentration to determine yield on a mass basis using the molecular weight of each FA while correcting for glycerol content and other milk lipid classes (Piantoni et al., 2013).

\section{Statistical Analysis}

All data were analyzed using the mixed model procedure of SAS (version 9.4, SAS Institute Inc., Cary, NC) according to the following model:

$$
\begin{gathered}
\mathrm{Y}_{\mathrm{ijk}}=\mu+\mathrm{C}_{\mathrm{i}}+\mathrm{P}_{\mathrm{j}}+\mathrm{T}_{\mathrm{k}}+\mathrm{P}_{\mathrm{j}} \times \mathrm{T}_{\mathrm{k}} \\
+\mathrm{PMY}+\mathrm{PMY} \times \mathrm{T}_{\mathrm{k}}+\mathrm{e}_{\mathrm{ijk}},
\end{gathered}
$$

where $\mathrm{Y}_{\mathrm{ijk}}=$ dependent variable, $\mu=$ overall mean, $\mathrm{C}_{\mathrm{i}}$ $=$ random effect of cow $(\mathrm{i}=1$ to 32$), \mathrm{P}_{\mathrm{j}}=$ fixed effect of period ( $\mathrm{j}=1$ to 2$), \mathrm{T}_{\mathrm{k}}=$ fixed effect of treatment $(\mathrm{k}=$ $1,2), \mathrm{P}_{\mathrm{j}} \times \mathrm{T}_{\mathrm{k}}=$ interaction between period and treatment, $\mathrm{PMY}=$ preliminary milk yield used as covariate, $\mathrm{PMY} \times \mathrm{T}_{\mathrm{k}}=$ interaction between PMY and treatment, and $\mathrm{e}_{\mathrm{ijk}}=$ residual error. Linear and quadratic effects for the interaction between PMY and treatment were added to evaluate responses to treatment by level of milk yield. We did not observe a quadratic interaction between PMY and treatment (all $P>0.30$ ) or an effect of treatment sequence; therefore, these were removed from the final model. Normality of the results were tested using box plots, normal probability, and homogeneity of variances. Main effects were declared significant at $P \leq 0.05$, and tendencies were declared at $0.05<P \leq 0.10$. Interactions were deemed significant at $P<0.10$ and tendencies at $P \leq 0.15$.

\section{RESULTS}

\section{Nutrient Intake and Total-Tract Digestibility}

We observed an interaction between treatment and PMY for DMI $(P=0.04)$, NDF intake $(P=0.05)$, total FA intake $(P=0.06)$, and absorbed 16-carbon FA $(P=0.08$; Table 3$)$. Interactions indicated that responses were positively and linearly related to PMY; for low-producing cows, DMI and nutrient intake were greater for cows fed with PA compared with $\mathrm{PA}+\mathrm{OA}$, whereas for high-producing cows, DMI and nutrient intake were lower for cows fed with PA compared with $\mathrm{PA}+\mathrm{OA}$ (Figure 1). Overall, compared with $\mathrm{PA}+\mathrm{OA}$, PA increased 16-carbon FA intake $(P<0.01)$ and decreased 18-carbon FA intake $(P<0.01)$. Compared with $\mathrm{PA}+\mathrm{OA}$, PA decreased total $(P<0.01)$, 16-carbon $(P<0.01)$, and 18 -carbon $(P<0.01)$ FA digestibility. The PA treatment decreased total FA absorption $(P=$ $0.03)$, increased 16-carbon FA absorption $(P<0.01)$, and decreased 18-carbon FA absorption $(P<0.01)$ compared with $\mathrm{PA}+\mathrm{OA}$. No differences were observed for NDF digestibility $(P=0.71)$ or DM $(P=0.81)$ digestibility between treatments.

\section{Production Results}

We observed a tendency for an interaction between treatment and PMY for milk yield $(P=0.12$; Table 4). The interaction indicated that higher-producing cows responded more favorably to $\mathrm{PA}+\mathrm{OA}$ than did lower-producing cows (Figure 2). We also observed an interaction between treatment and PMY for 3.5\% FCM $(P=0.05)$ and $\operatorname{ECM}(P=0.04)$. Interactions indicated that responses were positively and linearly related to PMY; for low-producing cows, 3.5\% FCM and ECM (Figure 3) were greater for cows fed PA compared with those fed PA+OA, whereas for high-producing cows, $3.5 \%$ FCM and ECM were lower for cows fed PA compared with those fed $\mathrm{PA}+\mathrm{OA}$. Overall, compared with $\mathrm{PA}+\mathrm{OA}, \mathrm{PA}$ increased milk fat content $(P=0.03)$, fat yield $(P<0.01)$, and protein yield $(P=0.03)$, with a tendency to increase protein concentration $(P=0.07)$ and milk lactose yield $(P=0.09)$. No treatment differences were observed for $\mathrm{BW}, \mathrm{BW}$ change, BCS, or BCS change between treatments $(P>0.10)$.

\section{Milk Fatty Acid Concentrations and Yields}

Milk FA are derived from 2 sources: $<16$ carbon FA derived from de novo synthesis in the mammary gland and $>16$ carbon FA originate from extraction from plasma. Mixed-source FA (C16:0 and cis-9 C18:1) origi- 


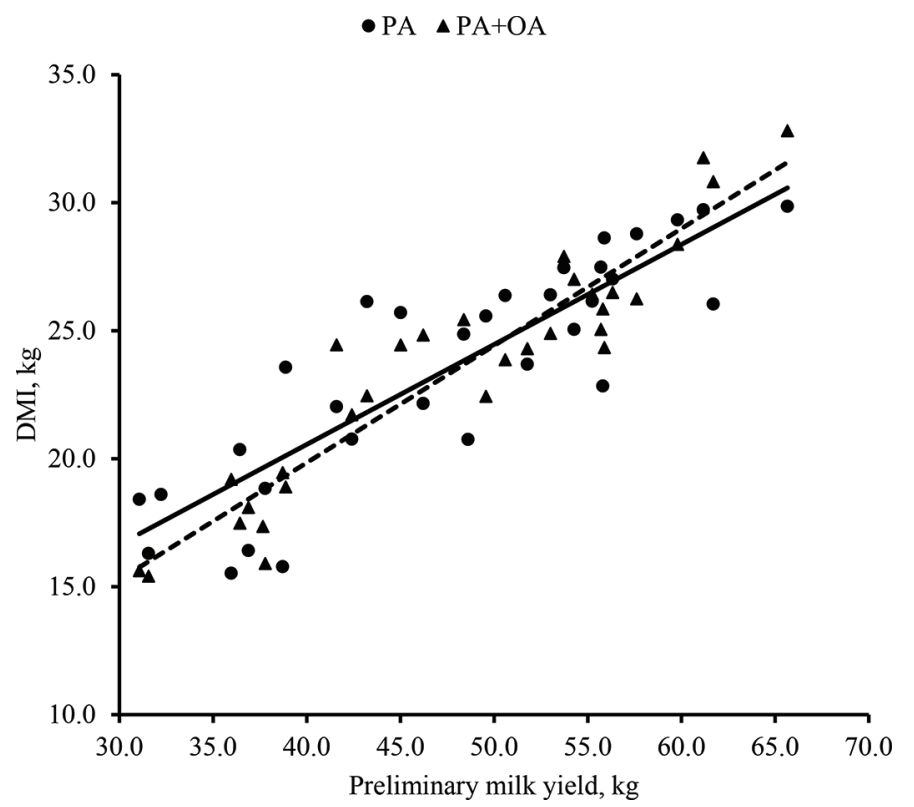

Figure 1. Relationship between preliminary milk yield (PMY) and DMI of cows fed a diet supplemented with either a high C16:0 blend (PA; 80\% C16:0, 10\% cis-9 C18:1) or a C16:0 and cis-9 C18:1 blend (PA+OA; 60\% C16:0, 30\% cis-9 C18:1). A treatment by PMY interaction was observed $(P=0.04)$ for DMI, whereby DMI was higher for low-producing cows receiving PA compared with $\mathrm{PA}+\mathrm{OA}$, whereas DMI was lower for high-producing cows receiving PA compared with PA+OA. Equation for PA: DMI $(\mathrm{kg} / \mathrm{d})=4.93+0.39 \mathrm{x} \times \mathrm{PMY}(\mathrm{kg} / \mathrm{d})$; $\mathrm{R}^{2}=0.76 ; P<0.05(\bullet$, solid line). Equation for PA+OA: DMI $(\mathrm{kg} / \mathrm{d})$ $=1.55+0.457 \mathrm{x} \times \operatorname{PMY}(\mathrm{kg} / \mathrm{d}) ; \mathrm{R}^{2}=0.88 ; P<0.05(\boldsymbol{\Lambda}$, broken line $)$.

nate from de novo synthesis in the mammary gland and extraction from plasma. A tendency for an interaction between treatment and PMY was observed $(P=0.14$; Table 5) for de novo yield because lower-producing cows responded more favorably to $\mathrm{PA}$ than to $\mathrm{PA}+\mathrm{OA}$ compared with higher-producing cows (Figure 4A). An interaction between treatment and PMY was observed $(P=0.08)$ for mixed FA yield, whereby lower-producing cows responded more favorably to $\mathrm{PA}$ than to $\mathrm{PA}+\mathrm{OA}$ compared with higher-producing cows (Figure 4B). Compared with $\mathrm{PA}+\mathrm{OA}$, PA increased de novo $(P<$ $0.01)$ and mixed-source $(P<0.01)$ FA yields and decreased preformed FA yield $(P<0.01)$. The PA treatment increased the concentration of mixed-source FA $(P<0.01)$ and tended to decrease the concentration of preformed milk FA $(P=0.08)$ compared with $\mathrm{PA}+\mathrm{OA}$. These changes were driven by increases in 16-carbon FA with $\mathrm{PA}$, whereas $\mathrm{PA}+\mathrm{OA}$ increased or tended to increase all 18-carbon FA (Supplemental Tables S1 and S2; https://doi.org/10.3168/jds.2020-18936).

\section{Blood Metabolites}

No interactions were observed between treatment and PMY $(P>0.15$; Table 6$)$. We observed no treatment differences for plasma insulin $(P=0.36)$ or BHB $(P=$ $0.17)$. Compared with $\mathrm{PA}+\mathrm{OA}, \mathrm{PA}$ decreased plasma NEFA concentration $(P=0.04)$.

\section{DISCUSSION}

Increasing the energy density of the ration through supplementation of FA can positively affect milk and component yields (Rabiee et al., 2012). Determining the ideal FA or FA profile needed for a cow is one way to maximize milk yield and production efficiency. Recently, research has focused on different FA and

Table 3. Nutrient intake and nutrient digestibility for cows fed treatment diets $(\mathrm{n}=32)$

\begin{tabular}{|c|c|c|c|c|c|c|}
\hline \multirow[b]{2}{*}{ Variable } & \multicolumn{2}{|c|}{ Treatment $^{1}$} & \multirow[b]{2}{*}{ SEM } & \multicolumn{3}{|c|}{$P$-value ${ }^{2}$} \\
\hline & $\mathrm{PA}$ & $\mathrm{PA}+\mathrm{OA}$ & & Trt & PMY & Trt $\times$ PMY \\
\hline DM, kg/d & 23.6 & 23.3 & 0.32 & 0.34 & $<0.01$ & 0.04 \\
\hline $\mathrm{NDF}, \mathrm{kg} / \mathrm{d}$ & 9.79 & 9.84 & 0.13 & 0.80 & $<0.01$ & 0.05 \\
\hline Total fatty acids (FA), $\mathrm{g} / \mathrm{d}$ & 1,050 & 1,069 & 14.3 & 0.37 & $<0.01$ & 0.06 \\
\hline 16-Carbon & 475 & 384 & 6.09 & $<0.01$ & $<0.01$ & 0.04 \\
\hline DM & 63.1 & 63.2 & 0.36 & 0.81 & 0.27 & 0.69 \\
\hline NDF & 38.1 & 38.4 & 0.64 & 0.71 & 0.01 & 0.88 \\
\hline Total FA & 74.0 & 77.6 & 0.94 & $<0.01$ & 0.86 & 0.38 \\
\hline 16-Carbon & 74.2 & 76.9 & 0.79 & $<0.01$ & 0.96 & 0.87 \\
\hline 18-Carbon & 73.0 & 79.3 & 1.35 & $<0.01$ & 0.92 & 0.30 \\
\hline \multicolumn{7}{|l|}{ Absorbed, g/d } \\
\hline Total FA & 787 & 828 & 14.1 & 0.03 & 0.01 & 0.21 \\
\hline
\end{tabular}

${ }^{1} \mathrm{PA}=1.5 \%$ of $\mathrm{FA}$ blend providing $80 \% \mathrm{C} 16: 0$ and $10 \%$ cis-9 $\mathrm{C} 18: 1 ; \mathrm{PA}+\mathrm{OA}=1.5 \%$ of $\mathrm{FA}$ blend providing $60 \% \mathrm{C} 16: 0$ and $30 \%$ cis-9 $\mathrm{C} 18: 1$.

${ }^{2} P$-values associated with treatment (Trt), production level (preliminary milk yield, PMY), and interaction. 
Table 4. Milk yield, milk composition, BW, and BCS of cows fed treatment diets $(\mathrm{n}=32)$

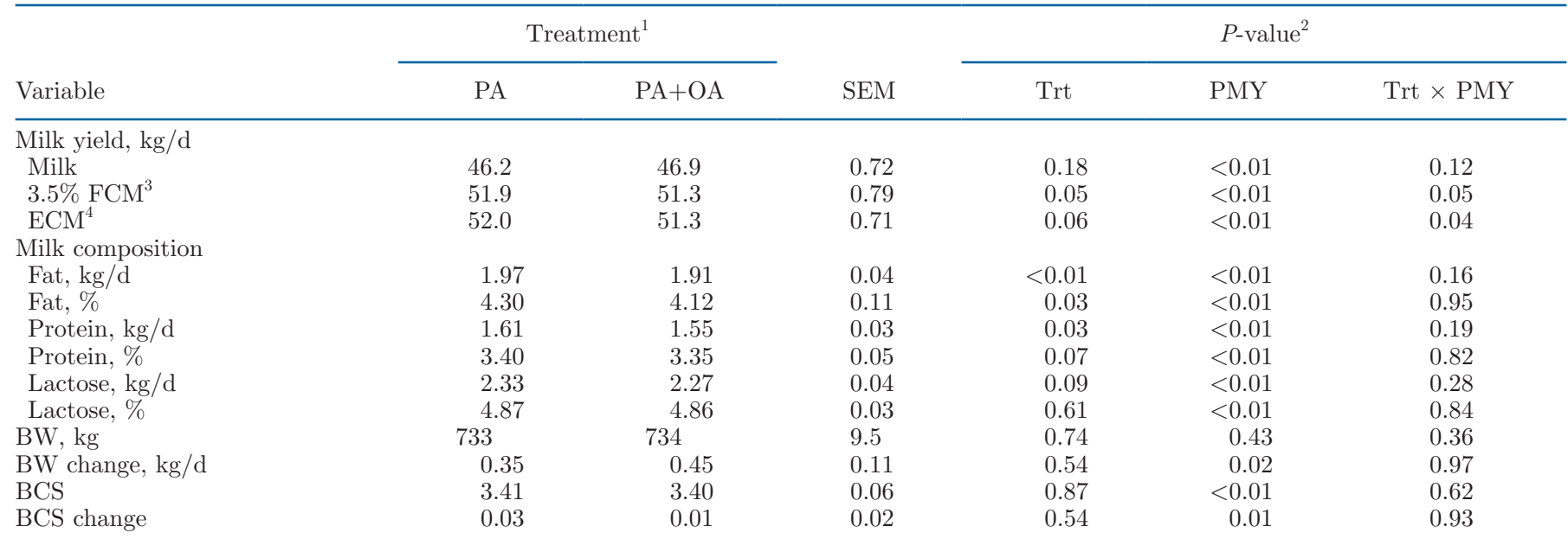

${ }^{1} \mathrm{PA}=1.5 \%$ of fatty acid (FA) blend providing $80 \% \mathrm{C} 16: 0$ and $10 \%$ cis-9 $\mathrm{C} 18: 1 ; \mathrm{PA}+\mathrm{OA}=1.5 \%$ of FA blend providing $60 \% \mathrm{C} 16: 0$ and $30 \%$ cis-9 C18:1.

${ }^{2} P$-values associated with treatment (Trt), production level (preliminary milk yield, PMY), and interaction.

${ }^{3} 3.5 \% \mathrm{FCM}=[(0.4324 \times \mathrm{kg}$ of milk $)+(16.216 \times \mathrm{kg}$ of milk fat $)]$.

${ }^{4} \mathrm{ECM}=[(0.327 \times \mathrm{kg}$ of milk $)+(12.95 \times \mathrm{kg}$ of milk fat $)+(7.20 \times \mathrm{kg}$ of milk protein $)]$. This equation corrects milk to a $0.68 \mathrm{Mcal} / \mathrm{kg}$ energy basis.

their effects on animal performance. C16:0 and cis-9 C18:1 are 2 FA that are commonly found in commercially available products (de Souza et al., 2018) and are also the main FA found in milk fat and adipose

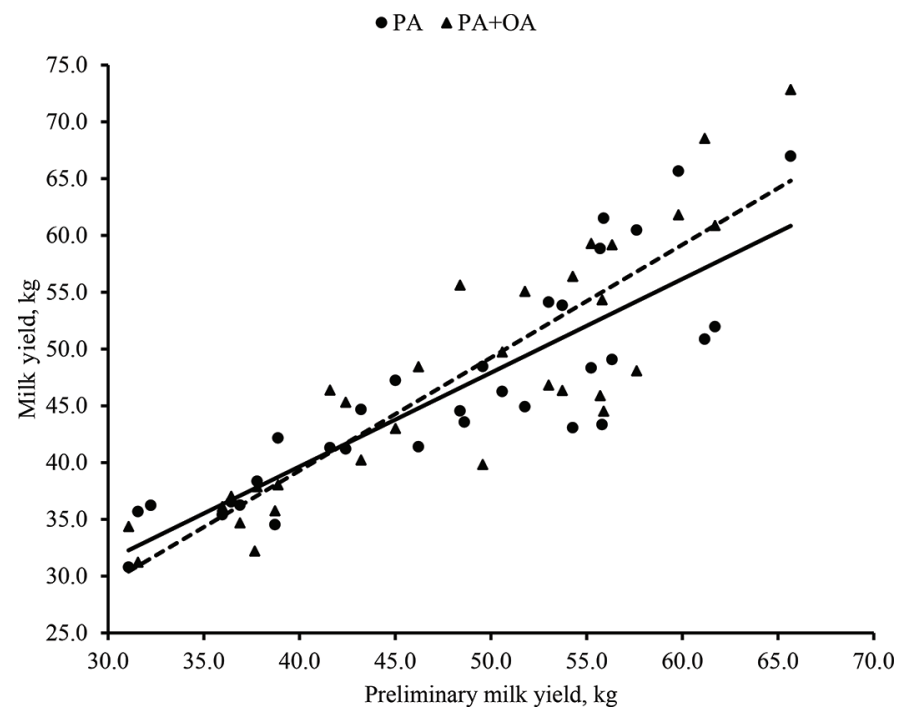

Figure 2. Relationship between preliminary milk yield (PMY) and milk yield of cows fed a diet supplemented with either a high C16:0 blend (PA; 80\% C16:0, 10\% cis-9 C18:1) or a C16:0 and cis-9 C18:1 blend (PA+OA; 60\% C16:0, 30\% cis-9 C18:1). A tendency for a treatment by PMY interaction was observed $(P=0.12)$ for milk yield, whereby higher-producing cows responded more favorably to PA+OA than to PA compared with lower-producing cows. Equation for PA: milk yield $(\mathrm{kg} / \mathrm{d})=6.62+0.83 \mathrm{x} \times \mathrm{PMY}(\mathrm{kg} / \mathrm{d}) ; \mathrm{R}^{2}=0.74 ; P<0.05$ (๑, solid line). Equation for PA+OA: milk yield $(\mathrm{kg} / \mathrm{d})=-0.49+$ $0.99 \mathrm{x} \times \mathrm{PMY}(\mathrm{kg} / \mathrm{d}) ; \mathrm{R}^{2}=0.78 ; P<0.05(\boldsymbol{\Lambda}$, broken line $)$. tissue (Jensen, 2002). C16:0 supplementation has been shown to increase milk yield and milk components (de Souza et al., 2018; Western et al., 2020), whereas cis-9 C18:1 has been shown to increase energy partitioning to body reserves (de Souza et al., 2018). We recently observed an interaction between production level and performance of cows when the ratio of $\mathrm{C} 16: 0$ and cis-9 C18:1 changed in FA supplement blends (de Souza et al., 2019). Results from this study showed that cows averaging $60 \mathrm{~kg} / \mathrm{d}$ responded better to increased levels of cis-9 C18:1, whereas cows averaging $45 \mathrm{~kg} / \mathrm{d}$ responded better to increased levels of C16:0. Although the de Souza et al. (2019) study included 3 production groups, the range in production level was only $15 \mathrm{~kg} / \mathrm{d}$, with the low group milk yield averaging $45 \mathrm{~kg} / \mathrm{d}$ and the high group $60 \mathrm{~kg} / \mathrm{d}$. Therefore, our objective in the current study was to observe the effects of C16:0 and cis-9 C18:1 on production and nutrient digestibility measurements in lactating cows across a wide range of milk production. Evaluating potential interactions between dietary strategies and production level is important. This information is readily available to the dairy industry and can be easily used for grouping strategies and feeding cows while considering other animal and management factors.

Previous research has found variable results on DMI due to fat supplementation. Saturated fat supplements have not altered DMI compared with no-added-fat controls (Harvatine and Allen, 2006; Rico et al., 2014a; de Souza et al., 2018). de Souza et al. (2018) observed that a blend of C16:0 and C18:1 (45\% C16:0 and 35\% C18:1) 


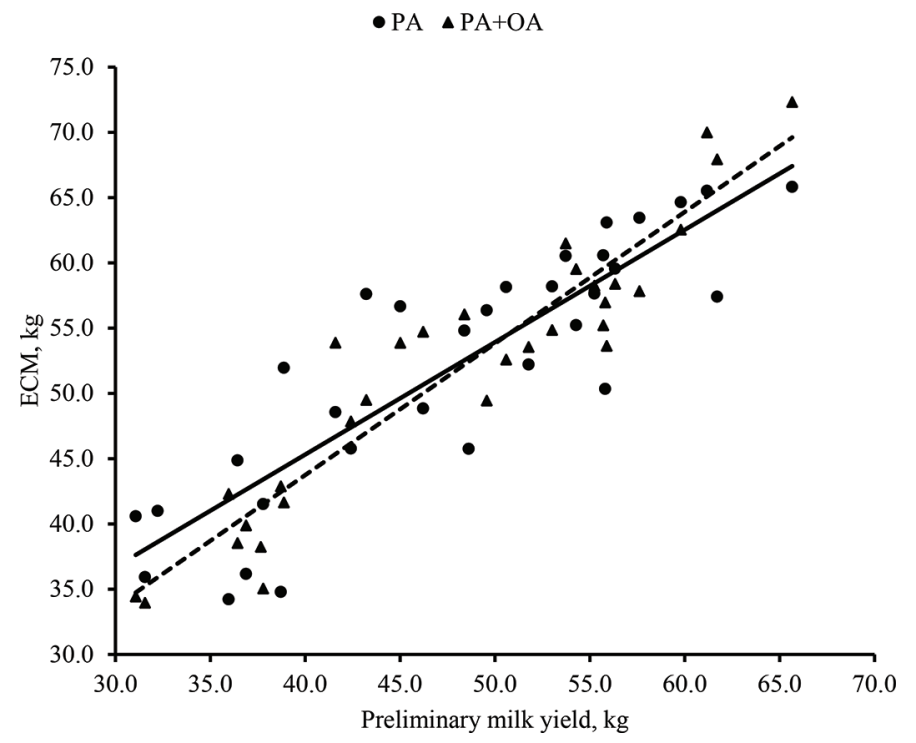

Figure 3. Relationship between preliminary milk yield (PMY) and ECM of cows fed a diet supplemented with either a high C16:0 blend (PA; 80\% C16:0, 10\% cis-9 C18:1) or a C16:0 and cis-9 C18:1 blend (PA+OA; 60\% C16:0, 30\% cis-9 C18:1). A treatment by PMY interaction was observed $(P=0.04)$ for ECM, whereby ECM was higher for low-producing cows receiving $\mathrm{PA}$ compared with $\mathrm{PA}+\mathrm{OA}$, whereas ECM was lower for high-producing cows receiving PA compared with $\mathrm{PA}+\mathrm{OA}$. Equation for PA: ECM $(\mathrm{kg} / \mathrm{d})=11.2+0.852 \mathrm{x} \times \mathrm{PMY}$ $(\mathrm{kg} / \mathrm{d}) ; \mathrm{R}^{2}=0.74 ; P<0.05(\bullet$, solid line). Equation for $\mathrm{PA}+\mathrm{OA}$ : $\operatorname{ECM}(\mathrm{kg} / \mathrm{d})=3.54+1.004 \mathrm{x} \times \mathrm{PMY}(\mathrm{kg} / \mathrm{d}) ; \mathrm{R}^{2}=0.86 ; P<0.05$ $(\boldsymbol{\Lambda}$, broken line $)$.

did not decrease DMI in a diet containing soyhulls, but DMI decreased in a diet containing whole cottonseed. In our study, we observed an interaction between DMI and PMY. Interestingly, higher-producing cows had increased DMI on the PA+OA treatment, whereas lower-producing cows had increased DMI on the PA treatment. This interaction between production level and treatment was not observed in our previous C16:0 and cis-9 C18:1 ratio study (de Souza et al., 2019).
Piantoni et al. (2015), however, observed increased intake with supplemental C18:0 in high-producing cows but not in low-producing cows. This increase in intake could be related to higher-producing cows having a greater energy requirement, and feed intake is likely under more physical (i.e., factors associated with gut distention) than metabolic (i.e., gut peptides, and oxidation of fuels) control mechanisms (Allen and Piantoni, 2014). However, previous research indicates that increasing the amount of cis-9 C18:1 reaching the small intestine would increase the risk of reducing DMI (i.e., Harvatine and Allen, 2006; de Souza and Lock, 2018a), which is different from what we observed in our study. The hypophagic effect of feeding fat seems to be more pronounced for unsaturated than for saturated FA supplements (Harvatine and Allen, 2006), with DMI decreasing linearly as the degree of unsaturation increases (Drackley et al., 1992; Pantoja et al., 1994) and the chain length of FA infused into the abomasum increases (Drackley et al., 1992). The more pronounced decrease in DMI for unsaturated FA is likely mediated in part by increased secretion of gut peptides related to satiety (i.e., cholecystokinin and GLP-1; Relling and Reynolds, 2007; Bradford et al., 2008). This may indicate that not only the amount of specific FA but also the profile are important factors affecting DMI. Further research needs to be conducted to determine the exact effects of FA profile on DMI and how it is affected by the metabolic demand of dairy cows.

Using total-tract digestibility measurements, we determined total, 16-carbon, and 18-carbon FA digestibility. The PA+OA treatment increased total, 16-carbon, and 18-carbon FA digestibility compared with the PA treatment. Similar to our results, de Souza et al. (2019) observed increases in total, 16-carbon, and 18-carbon FA digestibility with no interactions with production group. A recent meta-analysis indicated that not only

Table 5. Fatty acid (FA) concentrations and yields by source of milk FA for cows fed treatment diets $(\mathrm{n}=32)$

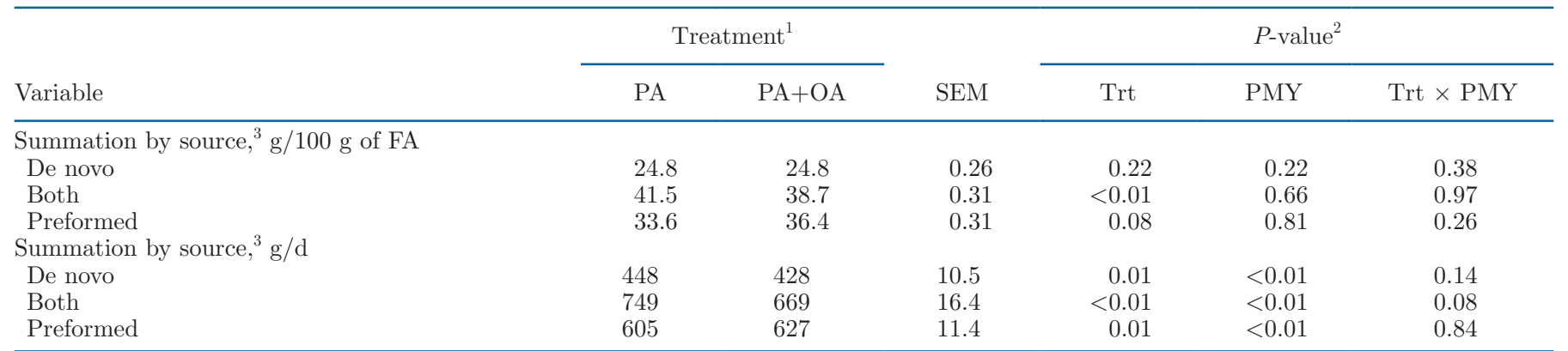

${ }^{1} \mathrm{PA}=1.5 \%$ of FA blend providing $80 \% \mathrm{C} 16: 0$ and $10 \%$ cis-9 C18:1; PA+OA $=1.5 \%$ of FA blend providing $60 \%$ C16:0 and 30\% cis-9 C18:1.

${ }^{2} P$-values associated with treatment (Trt), production level (preliminary milk yield, PMY), and interaction.

${ }^{3}$ De novo FA originated from mammary de novo synthesis (<16 carbons), preformed FA originated from extraction from plasma $(>16$ carbons), and mixed FA originated from both sources (C16:0 plus cis-9 C16:1). Concentrations and yields of individual FA are reported in Supplemental Tables S1 and S2, respectively (https://doi.org/10.3168/jds.2020-18936). 
Table 6. Blood metabolites for cows for treatment diets $(\mathrm{n}=32)$

\begin{tabular}{|c|c|c|c|c|c|c|}
\hline \multirow[b]{2}{*}{ Variable } & \multicolumn{2}{|c|}{ Treatment $^{1}$} & \multirow[b]{2}{*}{ SEM } & \multicolumn{3}{|c|}{$P$-value ${ }^{2}$} \\
\hline & PA & $\mathrm{PA}+\mathrm{OA}$ & & Trt & PMY & Trt $\times$ PMY \\
\hline Insulin, $\mu \mathrm{g} / \mathrm{L}$ & 0.97 & 0.94 & 0.04 & 0.36 & 0.01 & 0.58 \\
\hline NEFA, mEq/L & 0.12 & 0.13 & $<0.01$ & 0.04 & $<0.01$ & 0.17 \\
\hline $\mathrm{BHB}, \mathrm{mg} / \mathrm{dL}$ & 8.18 & 8.43 & 0.21 & 0.17 & 0.03 & 0.86 \\
\hline
\end{tabular}

${ }^{1} \mathrm{PA}=1.5 \%$ of fatty acid (FA) blend providing $80 \% \mathrm{C} 16: 0$ and $10 \%$ cis-9 $\mathrm{C} 18: 1 ; \mathrm{PA}+\mathrm{OA}=1.5 \%$ of $\mathrm{FA}$ blend providing $60 \% \mathrm{C} 16: 0$ and $30 \%$ cis-9 $\mathrm{C} 18: 1$.

${ }^{2} P$-values associated with treatment (Trt), production level (preliminary milk yield, PMY), and interaction.
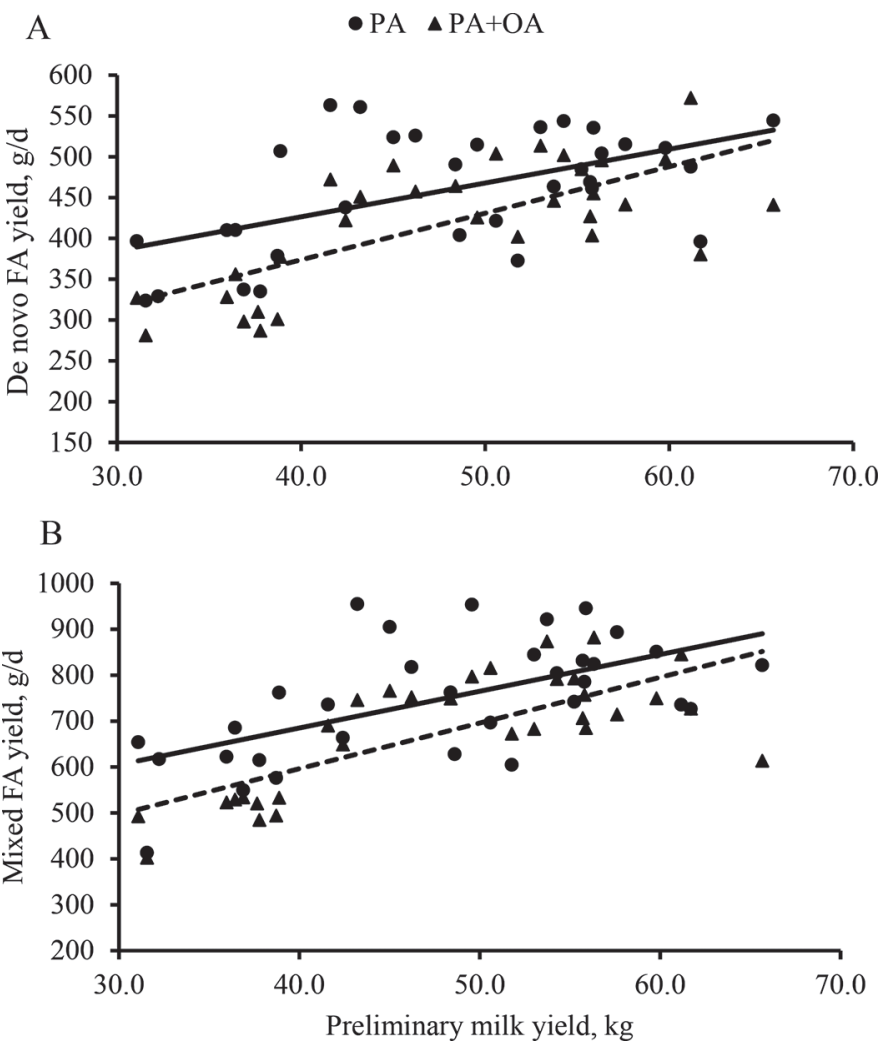

Figure 4. Relationship between preliminary milk yield (PMY) and yield of (A) de novo and (B) mixed fatty acids (FA) of cows fed a diet supplemented with either a high C16:0 blend (PA; 80\% C16:0, 10\% cis-9 C18:1) or a C16:0 and cis-9 C18:1 blend (PA+OA; 60\% C16:0, $30 \%$ cis-9 C18:1). A treatment by PMY interaction was observed $(P$ $=0.14$; panel A) for de novo FA yield, whereby lower-producing cows responded more favorably to $\mathrm{PA}$ than to $\mathrm{PA}+\mathrm{OA}$ compared with higher-producing cows. Equation for PA: de novo FA yield $(\mathrm{g} / \mathrm{d})=261+$ $4.14 \mathrm{x} \times \mathrm{PMY}(\mathrm{kg} / \mathrm{d}) ; \mathrm{R}^{2}=0.50 ; P<0.05(\bullet$, solid line). Equation for $\mathrm{PA}+\mathrm{OA}$ : de novo FA yield $(\mathrm{g} / \mathrm{d})=146+5.70 \mathrm{x} \times \mathrm{PMY}(\mathrm{kg} / \mathrm{d}) ; \mathrm{R}^{2}=$ $0.50(\boldsymbol{\Lambda}$, broken line). A treatment by PMY interaction was observed $(P=0.08$; panel $\mathrm{B})$ for mixed $\mathrm{FA}$ yield, whereby lower-producing cows responded more favorably to $\mathrm{PA}$ than to $\mathrm{PA}+\mathrm{OA}$ compared with higher-producing cows. Equation for PA: mixed FA yield $(\mathrm{g} / \mathrm{d})=365$ $+8.0 \mathrm{x} \times \mathrm{PMY}(\mathrm{kg} / \mathrm{d}) ; \mathrm{R}^{2}=0.54 ; P<0.05(\bullet$, solid line). Equation for PA+OA: mixed FA yield $(\mathrm{g} / \mathrm{d})=198+9.95 \mathrm{x} \times \mathrm{PMY}(\mathrm{kg} / \mathrm{d}) ; \mathrm{R}^{2}$ $=0.50 ; P<0.05(\boldsymbol{\Lambda}$, broken line $)$. does the flow of FA to the duodenum affect FA digestibility, but the FA profile reaching the duodenum also affects FA digestibility (Boerman et al., 2015a). Along these lines, Rico et al. (2017) observed that 16-carbon FA digestibility was reduced when feeding a C16:0 supplement $(85 \% \mathrm{C} 16: 0)$ to a greater extent in a soyhulls basal diet compared with a whole cottonseed basal diet. The effect of cis-9 C18:1 increasing total FA digestibility is likely due to cis-9 C18:1 having amphiphilic properties, which can assist in micelle solubility of C18:0 (Freeman, 1969; Moate et al., 2004). Additionally, unsaturated FA have faster uptake and re-esterification than saturated FA (Ockner et al., 1972). Additional research to understand the mechanisms by which cis-9 C18:1 may increase digestibility of other FA is required.

We observed no differences between treatments for NDF digestibility. Similarly, de Souza et al. (2019) reported no treatment differences when feeding different ratios of $\mathrm{C} 16: 0$ and cis-9 C18:1 similar to our treatments. Supplemental C16:0 has been shown to increase NDF digestibility compared with a no-added-fat control (Piantoni et al., 2013; Rico et al., 2017; de Souza et al., 2018). Results are variable for the effect of cis-9 C18:1 on digestibility, which may be related to different inclusion rates of supplements and the effects on DMI. In a recent meta-analysis, Weld and Armentano (2017) observed that calcium salts of palm FA supplements and saturated fat supplements containing a mixture of C16:0 and C18:0 did not affect NDF digestibility. Similar to previous studies, when C16:0 and C18:0 were supplemented across production levels (Piantoni et al., 2013, 2015), we also did not observe an interaction between PMY and treatment on DM and NDF digestibility.

Interestingly, we observed interactions between treatment and PMY for 3.5\% FCM and ECM because the yield of these variables was greater for low-producing cows fed PA and greater for high-producing cows fed $\mathrm{PA}+\mathrm{OA}$. Using the equation presented in Figure 3, using cow preliminary production, we can estimate a difference in ECM yield between PA and PA+OA of 2.3, 0.1 , and $-2.3 \mathrm{~kg} / \mathrm{d}$ for cows with PMY of 35,50 , and 
$65 \mathrm{~kg}$, respectively. Similar to our results, de Souza et al. (2019) observed that higher-yielding cows responded more favorably to a FA blend containing a higher content of cis-9 C18:1 for yields of milk and milk components compared with lower-yielding cows. Previous research has shown that production and metabolic responses to FA supplements can differ in cows at different levels of milk production (Harvatine and Allen, 2005; Warntjes et al., 2008). A previous study reported that C16:0 supplementation did not interact with level of milk production, and therefore, cows with a wide range of milk production responded similarly to treatment (Piantoni et al., 2013). Similarly, Rico et al. (2014b) compared C16:0 and C18:0 supplementation and concluded that C16:0 improved milk fat concentration and yield across all production levels more effectively than did C18:0. In contrast, DMI and milk production increased with C18:0 supplementation for higher-producing cows than for lower-producing cows (Piantoni et al., 2015). These results suggest that higher-producing cows might respond better to supplements containing 18-carbon FA. In contrast, Rico et al. (2014b) did not observe treatment differences for ECM when evaluating the effects of a C16:0 supplement and a Ca-salts of palm FA supplement in low- (average $34 \mathrm{~kg} / \mathrm{d}$ ) and high- (average $48 \mathrm{~kg} / \mathrm{d}$ ) producing cows. Although all the abovementioned studies were conducted with cows after peak production, there was a wide range in DIM within and across studies, which may suggest that other animal factors (e.g., pregnancy status, health) may interact with nutrition strategies, thereby affecting animal responses. Although we increased dietary cis-9 C18:1, it is likely that this treatment increased rumen outflow of other 18-carbon FA, so it is unclear whether these results are associated with an overall effect of 18-carbon FA or a specific FA. Gluconeogenesis in perfused liver of rats was stimulated by cis-9 C18:1 (Teufel et al., 1967), possibly indicating a role for this FA in mediating liver glucose metabolism. Also, previous studies reported that cis-9 C18:1 supplementation increased plasma insulin concentration (de Souza et al., 2018, 2019). Kronfeld (1982) suggested that the increased milk yield that occurs as a consequence of feeding supplemental fat to dairy cows is probably the result of improved efficiency of milk fat synthesis since incorporation of long-chain FA may reduce de novo FA synthesis and consequently spare gluconeogenic precursors used for NADPH generation. Whether specific FA are able to alter glucose metabolism, resulting in increased milk and ECM yields in high-producing cows needs to be determined. Although our study observed similar trends compared with de Souza et al. (2019), we did not see the magnitude of change that was previously reported. This could be because our wide range of production did not include as many very high producing cows as the previous study but covered lower-producing cows. Altogether, our results indicate that responses in milk yield and ECM of dairy cows to altering the FA profile of supplemental fat depends on cow production level, and that this factor should be considered when evaluating different FA supplements and nutritional management of dairy cows throughout lactation.

Additionally, previous studies suggest differences between C16:0 and cis-9 C18:1 on glucose metabolism and insulin sensitivity in vitro and in nonruminant animal models. For instance, cis-9 C18:1 improved C16:0 -induced mitochondrial dysfunction and contributed to the prevention of palmitate-induced insulin resistance in muscle cells (Yuzefovych et al., 2010). Also, cis-9 C18:1 elicits beneficial effects on insulin sensitivity and decreases diabetes risk in humans because of its capacity to inhibit endoplasmic reticulum stress, prevent attenuation of the insulin signaling pathway, and improve $\beta$ cell survival (Palomer et al., 2019). In dairy cows, our previous results have indicated that feeding cis-9 C18:1 not only increased BW gain in post-peak cows but also plasma insulin compared with non-FA-supplemented diets and other FA supplements (de Souza et al., 2018, 2019). Furthermore, de Souza et al. (2019) reported an interaction between FA treatments and production level for plasma insulin, whereby increasing dietary cis-9 C18:1 in FA treatments linearly increased plasma insulin in low-producing cows while quadratically affecting insulin in high-producing cows. Although in our study, we also observed interactions between the FA profile of the supplement and production level on production variables, we did not detect differences in plasma insulin or BW gain. However, it is possible that the differences in nutrient partitioning associated with the interaction between FA profile of the supplement and production level may be associated with change in insulin sensitivity. Further studies should evaluate the effects of cis-9 C18:1 on insulin sensitivity of dairy cows.

In our study, the effect of FA treatments on milk FA profile was influenced by production level. In lowproducing cows, increasing cis-9 C18:1 in supplemental fat decreased yields of de novo and mixed milk FA and increased the yield of preformed milk FA. In contrast, in high-producing cows, increasing cis-9 C18:1 in supplemental fat increased milk fat yield due to an increase in preformed milk FA without affecting the yield of de novo and mixed FA. Hansen and Knudsen (1987) reported that C16:0 stimulated de novo FA synthesis and incorporation into triglycerides, whereas other FA (C18:0, C18:1, and C18:2) had no effect in dispersed goat mammary epithelial cells. Dorea and Armentano (2017) observed, in a meta-analysis, a negative relation- 
ship between dietary cis-9 C18:1 content and de novo milk FA yield. This substitution effect of preformed for de novo milk FA has been reported previously ( $\mathrm{He}$ and Armentano, 2011; He et al., 2012), in which the reduction in yield of de novo milk FA was compensated for by an increase in the yield of preformed milk FA when fat supplements were fed. Our results indicate an interdependence between de novo and preformed FA in high-producing cows driving milk fat yield, whereas a substitution effect occurred in low-producing cows. Similar to our results, Piantoni et al. (2015) observed that C18:0 supplementation increased milk fat yield in higher-producing cows compared with lower-producing cows due to an increase in both de novo and preformed milk FA. Also, increasing C16:0 increased milk fat content and yield regardless of the level of milk production. The increased milk fat content and yield observed in our study is similar to that of previous research (Piantoni et al., 2013; Rico et al., 2017; de Souza et al., 2018). Yield of C4:0 was increased in the PA treatment compared with the $\mathrm{PA}+\mathrm{OA}$ treatment, which is consistent with previous research (Lock et al., 2013; Piantoni et al., 2013). This increase in C4:0 is a mechanism in the mammary gland to assist in milk fluidity as more longer-chain FA enter the mammary gland (Barbano and Sherbon, 1980; Glasser et al., 2008). Further research is needed to determine the mechanisms by which FA supplementation interacts with nutrient demand affecting milk fat synthesis.

\section{CONCLUSIONS}

Feeding FA supplements with higher levels of cis-9 C18:1 increased ECM and DMI and tended to increase milk yield as production level of cows increased, whereas supplements higher in C16:0 increased these variables in lower-producing cows. Overall, cis-9 C18:1 increased total, 16-carbon, and 18-carbon FA digestibility compared with C16:0, but no differences were observed on BW or BCS. Differences in production variables observed across a wide range of production suggest that supplementing specific ratios of $\mathrm{C} 16: 0$ and cis-9 C18:1 in FA blends to increase production measurements in lactating dairy cows should take into consideration the production level of cows.

\section{ACKNOWLEDGMENTS}

We are grateful to Perdue Agribusiness (Salisbury, MD) for financial support and donation of the supplements. We acknowledge Vita Plus (Madison, WI) for their support of M. Western through the Vita Plus Fellowship program and for support throughout the project. We recognize L. C. Worden, C. Prom, A. Pineda,
A. Negreiro, H. Sharrard, T. Kulpinski, E. Butler, and E. Schuurmans (all in the Department of Animal Science, Michigan State University, East Lansing), and the staff of the Michigan State University Dairy Cattle Teaching and Research Center for their help and assistance in this project. The authors have not stated any conflicts of interest.

\section{REFERENCES}

Allen, M. S., and P. Piantoni. 2014. Managing energy intake and partitioning through lactation. Vet. Clin. North Am. Food Anim. Pract. 30:577-597. https://doi.org/10.1016/j.cvfa.2014.07.004.

AOAC. 1990. Official Methods of Analysis. 15th ed. Vol. 2. AOAC, Arlington, VA.

Barbano, D. M., and J. W. Sherbon. 1980. Polyunsaturated protected lipid: Effect on triglyceride molecular weight distribution. J. Dairy Sci. 63:731-740. https://doi.org/10.3168/jds.S0022-0302(80)83000 -1 .

Boerman, J. P., J. de Souza, and A. L. Lock. 2017. Milk production and nutrient digestibility responses to increasing levels of stearic acid supplementation of dairy cows. J. Dairy Sci. 100:2729-2738. https://doi.org/10.3168/jds.2016-12101.

Boerman, J. P., J. L. Firkins, N. R. St-Pierre, and A. L. Lock. 2015a. Intestinal digestibility of long-chain fatty acids in lactating dairy cows: A meta-analysis and meta regression. J. Dairy Sci. 98:88898903. https://doi.org/10.3168/jds.2015-9592.

Boerman, J. P., S. B. Potts, M. J. VandeHaar, and A. L. Lock. 2015b. Effects of partly replacing dietary starch with fiber and fat on milk production and energy partitioning. J. Dairy Sci. 98:7264-7276. https://doi.org/10.3168/jds.2015-9467.

Bradford, B. J., K. J. Harvatine, and M. S. Allen. 2008. Dietary unsaturated fatty acids increased plasma glucagon-like peptide-1 and cholecystokinin and may decrease premeal ghrelin in lactating dairy cows. J. Dairy Sci. 91:1443-1450. https://doi.org/10.3168/ jds.2007-0670.

de Souza, J., and A. L. Lock. 2018a. Short communication: Comparison of a palmitic acid-enriched triglyceride supplement and calcium salts of palm fatty acids supplement on production responses of dairy cows. J. Dairy Sci. 101:3110-3117. https://doi .org/10.3168/jds.2017-13560.

de Souza, J., and A. L. Lock. 2018b. Long-term palmitic acid supplementation interacts with parity in lactating dairy cows: Production responses, nutrient digestibility, and energy partitioning. J. Dairy Sci. 101:3044-3056. https://doi.org/10.3168/jds.2017-13946.

de Souza, J., C. L. Preseault, and A. L. Lock. 2018. Altering the ratio of dietary palmitic, stearic, and oleic acids in diets with or without whole cottonseed affects nutrient digestibility, energy partitioning, and production responses of dairy cows. J. Dairy Sci. 101:172-185. https://doi.org/10.3168/jds.2017-13460.

de Souza, J., N. R. St-Pierre, and A. L. Lock. 2019. Altering the ratio of dietary C16:0 and cis-9 C18:1 interacts with production level in dairy cows: Effects on production responses and energy partitioning. J. Dairy Sci. 102:9842-9856. https://doi.org/10.3168/jds.2019 -16374 .

Dorea, J. R. R., and L. E. Armentano. 2017. Effects of common dietary fatty acids on milk yield and concentrations of fat and fatty acids in dairy cattle. Anim. Prod. Sci. 57:2224-2236. https://doi .org/10.1071/AN17335.

Douglas, G. N., J. Rehage, A. D. Beaulieu, A. O. Bahaa, and J. K. Drackley. 2007. Prepartum nutrition alters fatty acid composition in plasma, adipose tissue, and liver lipids of periparturient dairy cows. J. Dairy Sci. 90:2941-2959. https://doi.org/10.3168/jds.2006 -225 .

Drackley, J. K., T. H. Klusmeyer, A. M. Trusk, and J. H. Clark. 1992. Infusion of long-chain fatty acids varying in saturation and chain length into the abomasum of lactating dairy cows. J. Dairy Sci. 
75:1517-1526. https://doi.org/10.3168/jds.S0022-0302(92)77908 -9 .

Freeman, C. P. 1969. Properties of fatty acids in dispersions of emulsified lipid and bile salt and the significance of these properties in fat absorption in the pig and the sheep. Br. J. Nutr. 23:249-263. https://doi.org/10.1079/BJN19690032.

Glasser, F., A. Ferlay, M. Doreau, P. Schmidely, D. Sauvant, and Y. Chilliard. 2008. Long-chain fatty acid metabolism in dairy cows: A meta-analysis of milk fatty acid yield in relation to duodenal flows and de novo synthesis. J. Dairy Sci. 91:2771-2785. https://doi.org/ 10.3168/jds.2007-0383.

Goering, H. K., and P. J. Van Soest. 1970. Forage Fiber Analysis (Apparatus, Reagents, Procedures, and Some Applications). Agricultural Handbook no. 379. US Department of Agriculture-Agricultural Research Service (USDA-ARS), Washington, DC.

Hansen, H. O., and J. Knudsen. 1987. Effect of exogenous long-chain fatty acids on individual fatty acid synthesis by dispersed ruminant mammary gland cells. J. Dairy Sci. 70:1350-1354. https://doi .org/10.3168/jds.S0022-0302(87)80155-8.

Harvatine, K. J., and M. S. Allen. 2005. The effect of production level on feed intake, milk yield, and endocrine responses to two fatty acid supplements in lactating cows. J. Dairy Sci. 88:4018-4027. https://doi.org/10.3168/jds.S0022-0302(05)73088-5.

Harvatine, K. J., and M. S. Allen. 2006. Effects of fatty acid supplements on ruminal and total tract nutrient digestion in lactating dairy cows. J. Dairy Sci. 89:1092-1103. https://doi.org/10.3168/ jds.S0022-0302(06)72177-4.

He, M., and L. E. Armentano. 2011. Effect of fatty acid profile in vegetable oils and antioxidant supplementation on dairy cattle performance and milk fat depression. J. Dairy Sci. 94:2481-2491. https: //doi.org/10.3168/jds.2010-3755.

He, M., K. L. Perfield, H. B. Green, and L. E. Armentano. 2012. Effect of dietary fat blend enriched in oleic or linoleic acid and monensin supplementation on dairy cattle performance, milk fatty acid profiles, and milk fat depression. J. Dairy Sci. 95:1447-1461. https:// doi.org/10.3168/jds.2011-4635.

Jensen, R. G. 2002. The composition of bovine milk lipids: January 1995 to December 2000. J. Dairy Sci. 85:295-350. https://doi.org/ 10.3168/jds.S0022-0302(02)74079-4.

Kronfeld, D. S. 1982. Major metabolic determinants of milk volume, mammary efficiency. and spontaneous ketosis in dairy cows. J. Dairy Sci. 65:2204-2212. https://doi.org/10.3168/jds.S0022 $-0302(82) 82483-1$.

Lock, A. L., C. L. Preseault, J. E. Rico, K. E. DeLand, and M. S. Allen. 2013. Feeding a C16:0-enriched fat supplement increased the yield of milk fat and improved feed efficiency. J. Dairy Sci. 96:6650-6659. https://doi.org/10.3168/jds.2013-6892.

Moate, P. J., W. Chalupa, T. C. Jenkins, and R. C. Boston. 2004. A model to describe ruminal metabolism and intestinal absorption of long chain fatty acids. Anim. Feed Sci. Technol. 112:79-105. https: //doi.org/10.1016/j.anifeedsci.2003.10.007.

NRC. 2001. Nutritional Requirements of Dairy Cattle. 7th rev. ed. Natl. Acad. Sci., Washington, DC.

Ockner, R. K., J. P. Pittman, and J. L. Yager. 1972. Differences in the intestinal absorption of saturated and unsaturated long chain fatty acids. Gastroenterology 62:981-992. https://doi.org/10.1016/ S0016-5085(72)80115-X.

Palmquist, D. L. 2006. Milk fat: Origin of fatty acids and influence of nutritional factors thereon. Pages 43-92 in Advanced Dairy Chemistry. Springer, New York, NY.

Palmquist, D. L., and T. C. Jenkins. 2017. A 100-Year Review: Fat feeding of dairy cows. J. Dairy Sci. 100:10061-10077. https://doi .org/10.3168/jds.2017-12924.

Palomer, X., J. Pizarro-Delgado, E. Barroso, and M. Vazquez-Carrera. 2018. Palmitic and oleic acid: The yin and yang of fatty acids in type 2 diabetes mellitus. Trends Endocrinol. Metab. 29:178-190. https://doi.org/10.1016/j.tem.2017.11.009.

Pantoja, J., J. L. Firkins, M. L. Eastridge, and B. L. Hull. 1994. Effects of fat saturation and source of fiber on site of nutrient diges- tion and milk production. J. Dairy Sci. 77:2341-2356. https://doi .org/10.3168/jds.S0022-0302(94)77177-0.

Piantoni, P., A. L. Lock, and M. S. Allen. 2013. Palmitic acid increased yields of milk and milk fat and nutrient digestibility across production level of lactating cows. J. Dairy Sci. 96:7143-7154. https://doi .org/10.3168/jds.2013-6680.

Piantoni, P., A. L. Lock, and M. S. Allen. 2015. Milk production responses to dietary stearic acid vary by production level in dairy cattle. J. Dairy Sci. 98:1938-1949. https://doi.org/10.3168/jds .2014-8634.

Rabiee, A. R., K. Breinhild, W. Scott, H. M. Golder, E. Block, and I. J. Lean. 2012. Effect of fat additions to diets of dairy cattle on milk production and components: A meta-analysis and metaregression. J. Dairy Sci. 95:3225-3247.

Relling, A. E., and C. K. Reynolds. 2007. Feeding rumen-inert fats differing in their degree of saturation decreases intake and increases plasma concentrations of gut peptides in lactating dairy cows. J. Dairy Sci. 90:1506-1515. https://doi.org/10.3168/jds.S0022 $-0302(07) 71636-3$.

Rico, D. E., Y. Ying, and K. J. Harvatine. 2014a. Effect of a highpalmitic acid fat supplement on milk production and apparent total-tract digestibility in high- and low-milk yield dairy cows. J. Dairy Sci. 97:3739-3751. https://doi.org/10.3168/jds.2013-7341.

Rico, J. E., M. S. Allen, and A. L. Lock. 2014b. Compared with stearic acid, palmitic acid increased the yield of milk fat and improved feed efficiency across production level of cows. J. Dairy Sci. 97:1057-1066. https://doi.org/10.3168/jds.2013-7432.

Rico, J. E., J. de Souza, M. S. Allen, and A. L. Lock. 2017. Nutrient digestibility and milk production responses to increasing levels of palmitic acid supplementation vary in cows receiving diets with or without whole cottonseed. J. Anim. Sci. 95:436-446. https://doi .org/10.2527/JAS.2016.1089.

Rodney, R. M., P. Celi, W. Scott, K. Breinhild, and I. J. Lean. 2015. Effects of dietary fat on fertility of dairy cattle: A meta-analysis and meta-regression. J. Dairy Sci. 98:5601-5620. https://doi.org/ 10.3168/jds.2015-9528

Teufel, H., L. A. Menahan, J. C. Shipp, S. Boning, and O. Wieland. 1967. Effect of oleic acid on the oxidation and gluconeogenesis from $\left[1^{14} \mathrm{C}\right)$ pyruvate in the perfused rat liver. Eur. J. Biochem. 2:182-186. https://doi.org/10.1111/j.1432-1033.1967.tb00124.x.

Warntjes, J. L., P. H. Robinson, E. Galo, E. J. DePeters, and D. Howes. 2008. Effects of feeding supplemental palmitic acid (C16:0) on performance and milk fatty acid profile of lactating dairy cows under summer heat. Anim. Feed Sci. Technol. 140:241-257. https: //doi.org/10.1016/j.anifeedsci.2007.03.004.

Weld, K. A., and L. E. Armentano. 2017. The effects of adding fat to diets of lactating dairy cows on total-tract neutral detergent fiber digestibility: A meta-analysis. J. Dairy Sci. 100:1766-1779. https:/ /doi.org/10.3168/jds.2016-11500.

Western, M. M., J. de Souza, and A. L. Lock. 2020. Effects of commercially available palmitic and stearic acid supplements on nutrient digestibility and production responses of lactating dairy cows. J. Dairy Sci. 103:5131-5142. https://doi.org/10.3168/jds.2019-17242.

Wildman, E. E., G. M. Jones, P. E. Wagner, R. L. Boman, H. F. Troutt Jr., and T. N. Lesch. 1982. A dairy cow body condition scoring system and its relationship to selected production characteristics. J. Dairy Sci. 65:495-501. https://doi.org/10.3168/jds .S0022-0302(82)82223-6.

Yuzeforych, L., G. Wilson, and L. Rachek. 2010. Different effects of oleate vs. palmitate on mitochondrial function, apoptosis, and insulin signaling in L6 skeletal muscle cells: Role of oxidative stress. Am. J. Physiol. Endocrinol. Metab. 299:E1096-E1105. https://doi .org/10.1152/ajpendo.00238.2010.

\section{ORCIDS}

Jonas de Souza () https://orcid.org/0000-0002-7686-7079

Adam L. Lock @ https://orcid.org/0000-0002-9282-399X 